\title{
People with Disabilities and Their Representation in Public Spaces: A Case Study of Post-War Jaffna
}

N. Baskaran

\author{
Department of Sociology, Faculty of Social Sciences, South Asian University,
} New Delhi, India.

\begin{abstract}
People with disabilities have become an important topic for discussion in the postwar Sri Lanka due to many reasons. In Northern Sri Lanka, different age group of the population in war-torn areas are often direct or indirect victims of violence, and witnesses to various issues associated with war disaster. Over three decades of war in Sri Lanka has changed the traditional views of disability and replaced it with a view of disability as a social oppression. This study, therefore, looks to understand the social background of people with disabilities. The main objective of this study is to consider the meaning of disabilities in public spaces in post-war Jaffna ${ }^{1}$. The chosen field was undertaken in Thenmaradchi Divisional Secretariat of Jaffna district. This paper has reported on the experiences of 59 people with disabilities who were disabled during the war period. The primary data were collected from interviews and surveys with predetermined case study, non-direct and participant observation and key informant interviews through purposive sampling.
\end{abstract}

It is in this context; an attempt is made to understand the meaning of people with disabilities through their day-to-day life events, situations, and their experiences. This paper discusses the meaning of disabilities under three factors namely, Religious Discourse, Family Structure and Women Status based on grounded theory method. Moreover, these socio-cultural interpretations of people with disabilities are linked with other important factors such economic and political aspects. The finding of the study was that the people with disabilities depicted there are usually crippled and socially excluded or hidden in the limited public spaces in postwar Jaffna. Since disability issues have become a central part of the development and social work discourse in the post-war Tamil society, the researcher hopes that this research will contribute to policy formation for people with disabilities and the effective implications of the post-war reintegration process and development process. Finally, it is hoped that the study will create social awareness and mobilize people with disabilities and strengthen the disabled in society.

Keywords: People with disabilities, Post-War, Public spaces, Representations

\section{INTRODUCTION}

Loss and bereavement are an important part of anybody's life. A person has to go through this experience at some point in his or her life. It can bring immense emotional trauma and suffering to the person left behind by the dead. The experience of loss is even more distressing when the death of a person brings additional social stigma. Such is the experience of

\footnotetext{
1 Jaffna is a capital city in the Northern Province of Sri Lanka. It is also one of the districts of Sri Lanka as well. Located in Northern Province, which is about $410 \mathrm{~km}$ away from Colombo. It is one of the major Tamil cultural hubs in the country. In Tamil language, Yalpanam (it means "playing a kind of instrument") and a place is an avenue. Jaffna District has divided into four Subdivisions. They are Islands, Valikamam, Thenmaradchi, and Vadamaradchi.
} 


\section{N.Baskaran \\ People with Disabilities and Their Representation in Public Spaces: A Case Study of Post-War Jaffna}

disabilities in post-war in Sri Lanka. People with disabilities face various forms of social exclusion through barriers of public places (WHO 2011, Shakespeare 1999). According to Foucault (1986:24) spaces are the places that exist which could be found in the general society which has a real location. Lefebvre (1991:64) has connected his idea about spaces with the production of spaces assuming that every society produces its specific spaces. Accordingly, he was of the view that the specialization connected with the individual through spatial practices and representations. Public spaces play a broad range, which can be classified as physical, ecological, psychological, social, political, economic symbolic and aesthetic roles.

War has plagued humans since time immemorial. War is now well known to cause a variety of social deprivations ${ }^{2}$. In Northern Sri Lanka, different age group of the population in wartorn areas are often direct or indirect victims of violence, and witnesses to various issues associated with war disaster. People with disabilities have become an important topic for discussion in the post-war Sri Lanka due to many reasons. Many thinkers believe that the thirty years of war created a number of civilians, LTTE combatants and military soldiers with disabilities. In Sri Lanka, $6.6 \%$ of the general population is 65 years or older, with $22.5 \%$ people with disabilities (WHO 2011:35). Over three decades of war changed the traditional views of disability (and replace it with a view of disability as a social oppression in Northern Sri Lanka. All the disabled are considered as war victims and are concentrated largely in the Northern and Eastern part of the country. Over 110,000 people were disabled by war struggle along with very little official assistance in Northern Sri Lanka (Perera 2016).

Government soldiers with disabilities can receive assistance packages for injuries sustained in service, including the continuation of salaries for those able to work at desk jobs, or long-term care in military-run facilities for those severely disabled. But there is no program to help civilians and former Tamil Tigers who remain permanently affected by injuries during the war (Perera2015). Therefore, the two communities in Sri Lanka (Tamils and Sinhalese), received different benefits from the state and also community is determined by caste, gender, ethnic group and others. In such a social context, the mobilization and reintegration ${ }^{3}$ process of disabled people is problematic in post-war in Sri Lanka.

Compared to other conflict-affected countries, research on people with disabilities in Sri Lanka has been minimal, and the few studies available on people with disabilities in Sri Lanka are nevertheless information. This research attempts to understand the processes of socio-cultural interpretation of people with disabilities in public spaces of post-war. Basically, it attempts to understand the people with disabilities and their representations through the study of the events, situations, and their experiences are these involved with or engage everyday activities in. Since disability issues have become a central part of the development and social work discourse in the post-war Tamil society, the researcher hopes that this research will contribute to policy formation for people with disabilities and the effective implications of the post-war reintegration process and development process. Finally, it is hoped that the study will create social awareness and mobilize people with disabilities and strengthen the disabled in Sri Lanka.

\subsection{Aim of the study}

The main objective of this study is to consider the people with disabilities and their representation in the public spaces in post-war Jaffna, Sri Lanka. The following research questions are proposed for the purpose of conducting the present research;

$>$ What are the socio-cultural interpretations of disabilities in the public spaces in the post-war Jaffna?

\footnotetext{
2 Social Deprivation can cause psychosocial and socio-cultural changes in society.

${ }^{3}$ Re-integrating refers to developing a sense of belonging, self-containment, and happiness. The mentioned indicators are measures to attain sustainable peace.
} 


\section{N.Baskaran \\ People with Disabilities and Their Representation in Public Spaces: A Case Study of Post-War Jaffna}

$>$ In particular, what are the existing social and cultural perceptions of people with disabilities in the public spaces of Jaffna society?

> How do above socio - cultural perceptions affect people with disabilities in public spaces of post-war Jaffna?

\section{LITERATURE REVIEW}

\section{Existing Literature on People with Disabilities and their Representation in the Public spaces}

In mush of the literature significant, disabilities are related to public spaces. Space is the medium in which people act, intersect, move and locate themselves. Public and private spaces are sharply separated from each other in contemporary societies. People with disabilities are often excluded from public space and sequestered in private or institutional spaces (Freund, 2010:694-697). Accordingly, Demoes (2013) has defined public space, from being was temporarily opened up, and being totally controlled and owned, to one where people could stop, see, talk and engage with presentations and other people (Demos 2013:158). Sociologically, sociologist spatial research focuses natural and social space and also on also how individuals and collectivizes life uses these and how both kinds of spaces affect them. There are some approaches to space discussed by spatial sociologists, including new concepts of Land use, location, density, propinquity, neighborhood, community and political economy (Herbert, 2002). According to Foucault (1986:24) spaces (Heterotopias) are the places that exist which could be found in the general society which has a real location. Lefebvre (1991:64) has connected his idea about spaces with the production of spaces assuming that every society produces its specific spaces. Accordingly, he was of the view that the socialization is connected with the individual through spatial practices and representations.

Several studies highlight that disabilities play a role in bringing positive and negative changes and their representation in the public spaces of people with disabilities. The negative changes in lifestyle due to disabilities are; changing the actives, leading an inactive and incapable life, losing confidence, frustration and desperation, being a burden on family members, suppressing sexual urge, decline in marriage prospects, access to the collective religious practices, becoming societal deviants and useless people, and isolation (Anderson \& Whitfield 2013; Chen \& Shu 2012; Hussain 2005; Selway \& Ashman 1998, cited from Bunning \& Steel 2006). As Douglas C. McMurtrie (1919) mentions in the far East, the tribes of ancient India turned out their deformed member to wander in the wilderness and perish of exposure; in America, among the Aztecs, deformed persons were sacrificed in time of famine and need, on the death of a king and great men. Primitive society abandoned, expelled, put to death its disabled and deformed members (McMurtrie 1919: 01). Therefore, people with disabilities have been not accepted as normal people in society. They have been excluded from the larger society. Jayne Clapton and Jennifer Fitzgerald (2014) mention that for people with disability, their history is largely a history of silence. The lives of people with disability have not only been constructed as 'Other' but frequently as 'the other' of 'the other'. People with disability are marginalized even by those who are themselves marginalized (Clapton \& Fitzgerald 2014). On the one hand, these findings do not cover the influence and the role of religion, family, and education in positive representation. On the other hand, these findings do not cover the people with disabilities. However, these findings give insights in understanding negative influences of disability. In addition, these findings assist the researcher to think about how this kind of negative influence effects to create new social responsibilities to the people with disabilities Jaffna, Sri Lanka.

On the contrary, these negative influences and responses towards the disabilities, Peter Freund (2001) mentions that 'like any label, being labelled as a 'person with a disability' has sociopolitical consequences ranging from exclusion (e.g. job discrimination) to the ability to claim 'special' accommodation (e.g. parking spaces for 'people with disabilities')' (Freund 2001: 


\section{N.Baskaran \\ People with Disabilities and Their Representation in Public Spaces: A Case Study of Post-War Jaffna}

692). Steven J. Taylor (2000) mentions that 'even when people's disabilities are recognized as in the case of the handicapped, these disabilities do not represent a master status that controls interactions with them' (Taylor 2000: 84). These insights help in exploring how the people with disabilities identify themselves either as war victims or just as other people with disabilities, and the positive and negative influences of being the people with disabilities in the post-war in Jaffna.

\section{Approaches to disability studies and influences of disability}

There are a few approaches to the understanding of the people with disabilities. They are; the religious model of disability, the medical/genetic model of disability, the social model of disability and the rights-based model of disability' (Clapton \& Fitzgerald 2014). According to religious model of disability, disability does not just relate present life. It connects with influences of gods' and evils, karma, past lives, past good and bad behaviors (Clapton \& Fitzgerald 2014; Dalal 2002). The medical model of disability focuses on 'individual body, rehabilitation, labeling, sense of personal tragedy, and highlights the personal defects and emphasizes social control and correction for people with disabilities (Chen \& Shu 2012; Clapton \& Fitzgerald 2014; Hussain 2005). Anthony Giddens (2009) defines this medical model as the individual model of disability. As Giddens (2009) mentions 'medical specialists play a central role in the individual model because it is their job to offer curative and rehabilitative diagnoses to the 'problems' suffered by the disabled individual (Giddens 2009: 416). Giddens (2009) further states that historically western societies, an individual model of disability have been dominant. This model contents that individual limitations are the main cause of problems experienced by disabled people (Giddens 2009: 416). This medical model has been criticized by the social model.

The social model of disability presents that the disability as a social construction, not as a personal ecological deficit. This model attempts to generate inclusionary policies and practices for people with disabilities (Barnes \& Mercer 2005; Chen \& Shu 2012; Chakravarti 2013; Hussain 2005; Oliver 1996). With regards to the disability of blindness, Robert A. Scott (1969) mentions that the disability of blindness is a learned social role. The various attitudes and patterns of behavior that characterize people who are blind are not inherent in their condition but, rather, are acquired through ordinary processes of social learning. Thus, there is nothing inherent in the condition of blindness that requires a person to be docile, dependent, melancholy, or helpless; nor is there anything about it that should lead him to become independent or assertive. Blind men are made and by the same processes of socialization that have made us all' (Scott 1969: 14). This social model also has been criticized by some scholars. Ruth Pinder (1995) argues that the social model takes a disembodied approach to solving problems. Social arrangements (e.g. the environment) can be overemphasized, since disability is not simply a social construction, but may, at least partly, reside in an 'objective' impairment and not just the complex in which a person is situated. Willians \& Busby (2000) mention that 'the social model ignores the bodily change and decay' (Pinder 1995, and Willians \& Busby 2000, cited from Freund 2001). These criticisms regarding the social model have been challenged by some scholars. Peter Freund (2001) mentions that 'it is equally important to not to neglect the socially constructed nature of categories, such as impairment and disabilities, and the contexts that can ameliorate or significantly decrease the transformation of impairments into disabilities' (Freund 2001: 691). Priestly (1999) also states that 'the discourses or public narratives that individual encounters on a daily basis will influence selfconcept and understanding of disability as a social construct' (Priestly 1999, cited from Bunning \& Steel 2006: 44).The rights-based model of disability, as Jayne Clapton and Jennifer Fitzgerald (2014) mention, embraces the conceptual shift from disability being seen as an individualized 'medical problem' to rather being about community membership and participation, and access to regular societal activities such as employment, education, recreation and so on. Where access is inappropriate, inadequate, difficult or ignored, advocacy processes have been initiated to address situations and promote the people's rights (Clapton 


\section{N.Baskaran \\ People with Disabilities and Their Representation in Public Spaces: A Case Study of Post-War Jaffna}

\& Fitzgerald 2014). These approaches are useful for a researcher to understand the intentions and responses of peoples, institutions, and states on people with disabilities.

\section{Stigmatization and People with disabilities}

Stigmatization is also related with the disability and their representation in the public spaces. According to Erving Goffman (1963), stigmatization emerges when there is a discrepancy between virtual social identity and actual social identity (Goffman 1963:2). Goffman (1963) presents the three grossly different types of stigma. First, there are abominations of the body - the various physical deformities. Next, there are blemishes of individual character perceived as the weak will, domineering or unnatural passions, treacherous and rigid beliefs, and dishonesty, these being inferred from a known record of, for example, mental disorder, imprisonment, addiction, alcoholism, homosexuality, unemployment, suicidal attempts, and radical political behavior. Finally, there is the tribal stigma of race, nation, and religion, these being the stigma that can be transmitted through lineages and equally contaminate all members of a family' (Goffman 1963: 4). Disability also comes under the abomination of the body. Therefore, certain types of bodily are not accepted as normal bodies. These bodies are abused, isolate, and assumed as helpless and dependent bodies (Clapton \& Fitzgerald 2014; McMurtrie 1919). Link and Phelan (2006) mention that 'stigmatization involves several components: labeling, stereotyping, cognitive separation, emotional reaction, status loss and exercise of power' (Link \& Phelan 2006, cited from Chen \& Shu 2012: 247). James Staples (2011) mentions 'the very act of labeling someone or something as 'stigmatised' changes the thing so labeled' (Staples 2011: 122). With regarding the disability, several studies underline from the social perspective, stigmatization occurs because of the influences of the medical model of social institutions such as social welfare, education system, health care services and rehabilitation. In addition, identity is most threatened in health and social care services because of overprotection, professional domination and lack of autonomy (Anderson \& Whitfield 2013; Chen \& Shu 2012). These findings help in understanding the influences of stigmatization, health care services and other social welfare services on the representation of people with disabilities in post-war Sri Lanka.

\section{RESEARCH METHODOLOGY}

\subsection{Research site}

People with disabilities have become an important topic for discussion in the post-war Sri Lanka due to many reasons. Jaffna is the most important district in the Northern Province. It was also not only a war-scarred area but people have also related faced war circumstance from time to time. The people of Jaffna have faced the displacement and other war-related issues. Normalcy is gradually returning to Jaffna finally after the end of the war in May 2009. However, one of the major issues that people with disabilities in post-war Jaffna face is the inability to represent of their life in public spaces. 


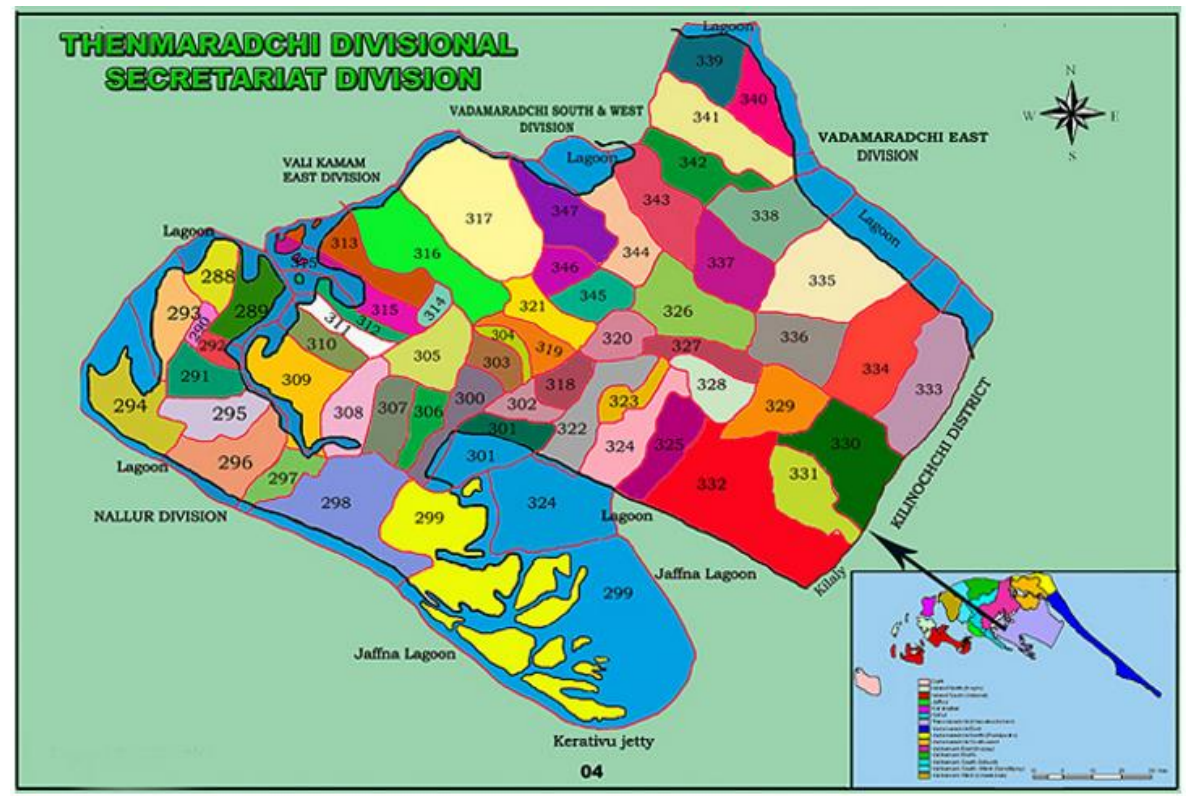

Figure 1.

(Source: Thenmaradchchi Divisional secretory profile, 2016)

Therefore, the chosen site is highly relevant for a study as it a very good sample of people with disabilities and their representation in post-war Jaffna. This study focuses on Thenmaradchi Divisional Secretariat of Jaffna. Thenmaradchi Divisional Secretariat is one of the 15 divisions of Jaffna district.

\subsection{Methods of Data Collection}

The method adopted for this research provides an opportunity to use evidence from multiple sources such as archival records, self-observation, and case study methods. The case study for this research can be an empirical inquiry that investigates a contemporary phenomenon within its real-life context. There are two types of data were collected. The primary data were collected from interviews and surveys with predetermined case study. The secondary data was collected from various journals, newspapers archives, and the internet.

As Yin (2004:1) suggested, as this study will be examining a real situation, the best methodology is the case study approach. Further, the study is an interpretive one looking at the narratives of the people with disabilities and their representation about their public spaces post-war period in Jaffna, Sri Lanka.

\section{Sample}

Under the purposeful sampling method, 'the researcher actively selects the most productive sample to answer the research question' (Marshall 1996: 523). Therefore, relationship with research participants is very important in qualitative research. This paper has reported on the experiences of 59 people (Ex-combatants and civilians) with disabilities who were disabled in the period. The participations were selected from a list of those who were registered as having disabilities by the divisional secretariat in Jaffna. 
Table: 1 Selection of Sample

\begin{tabular}{|l|l|c|}
\hline No & Details of Disabilities & Sample \\
\hline 1. & Ex-combatants (female) & 12 \\
\hline 2. & Ex-combatants (Male) & 11 \\
\hline 3. & Ex-combatant (widow) & 05 \\
\hline 4. & Ex-combatant (widower) & 03 \\
\hline 5. & Civilian (widow) & 07 \\
\hline 6. & Civilian (widower) & 04 \\
\hline 7. & Children & 05 \\
\hline 8. & Migrated ex-combatants & 02 \\
\hline 9. & Migrated (civilian) & 03 \\
\hline & & $\mathbf{5 2}$ \\
\hline & Key Informants & 03 \\
\hline 10. & Civilian (Male) & 04 \\
\hline 11. & Civilian (Female) & 59 \\
\hline & Total & \\
\hline
\end{tabular}

This study focused on people with the disability based on according to their nature of disabilities, various age groups, marital status, levels of education, and other social divisions, etc. It is expected to use data collected through documents, archival records, direct and participant observations had been made strategically.

\section{Grounded Theory}

Analysis of collected data is a continuous process after a research start. This study follows grounded theory for data analysis. Grounded theory is a particularly qualitative methodology which seeks to develop conceptual knowledge and frameworks that are grounded in the individual experience of research participants.

The reason for choosing grounded theory is, it requires inductive methods and uses constructive approach to constructing the meaning of data that this study found during a field visit. As a methodological approach, it allows researchers a great level of flexibility in the analytical process, to build mid-range theories in new and novel research contexts. Disability stories take the entire informant role in the method of qualitative analysis because this analysis tells us about the meaning of interpretation of their lives in disabled people's stories, feelings, emotion, and experiences. In this contract, this is very much related to the substantives descriptive in the broad sense that includes the description of disabilities, concepts, and beliefs.

\subsection{Interpretive Approach and Environmental Theory}

The interpretive approach highlights the important of the context and history of the meaning construction of representation. As researcher described previously, the people with disabilities are also living in different social contexts that are the war period and the post-war period in Jaffna Sri Lanka. Therefore, this interpretive approach helps to understand these different social contexts, its influences on the representation and the perspectives of the people with disabilities in the post-war period in Sri Lanka. 


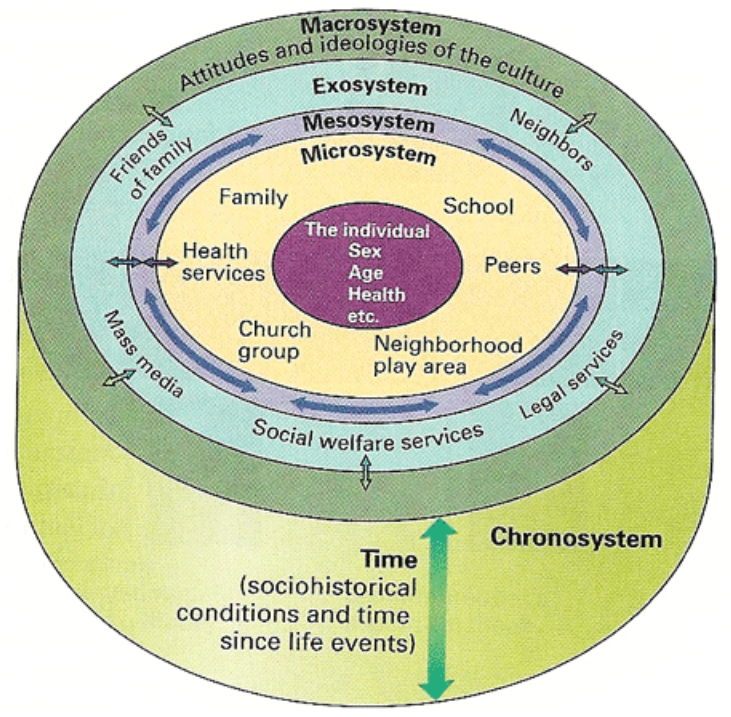

Figure 2.

Socio-cultural common sense informs us that the people with disabilities have faced many forms of representation in the post-war society. The environmental theory assumes that there are multidirectional interactions between an individual and their environment (Kotze 2003:368).

It focuses on how living experiences in an environment affects people and their day to day life. This is the best approach to understanding disability in contemporary post-war Sri Lankan. In this light, this study focuses on influences of the environmental and their living conditions of people with disabilities and their representation which they have to face in the post-war period. Accordingly, the environmental approach includes five systems of society, each one related to one another.

1. Microsystem focuses on how people with disabilities influence with family, neighborhoods, friends and school and so on.

2. Mesosystem relates to how collective experiences of the micro system influence the meaning of disability.

3. Exosystem refers to the interactions or social network they have in the public spaces primarily focused on the situation of the disabled.

4. Macro system focuses on disabled people within the framework of culture or cultural influences of individuals with disabilities

5. Chronosystem ruminates on the effect of the day to day life environmental events and living transformation on people with disabilities. It especially focuses on the sociohistorical understanding of disability.

The interpretive approach highlights the importance of the context and history of the meaning construction of representation. As researcher described previously, the people with disabilities are also living in different social contexts that are the war period and the post-war period in Jaffna Sri Lanka. Therefore, this interpretive approach helps to understand these different social contexts and its influences on the representation and the perspectives of the people with disabilities in the post-war period in Sri Lanka

\section{DATA ANALYSIS AND INTERPRETATION}

The information provided by the participants is organized and discussed around themes that emerged from the data. These themes are following: Religious discourse, family structure, and 


\section{N.Baskaran \\ People with Disabilities and Their Representation in Public Spaces: A Case Study of Post-War Jaffna}

women status. The data were only edited for the sake of clarity and brevity and, in the most part, are presenting here in briefly.

\section{Religious Discourse}

Religion is an essential element to explain a set of beliefs. It is more than ecology of themes for social communication rather it is a concrete way of interacting. It is cultural arbitrariness and systematic process. Each religion has different impacts on some aspects of people of the religious behaviour. These differences arise because of different values and beliefs revolve religious ideologies. Religion influences disabled person's personality, by the way, their beliefs, values, attitudes, affect their lifestyle and information sources.

In traditional Jaffna society, powerfully influenced by a Hindu worldview, it has come to dominate the religious space of the Jaffna society. The Hindu social organization based on a hierarchical division of occupational grouping or caste is firmly rooted in the peninsula. Religion is still so strong that the so-called untouchable caste (Panchamar) ${ }^{4}$ discrimination and people with disabilities. Most individuals with disabilities are supported by their families and by some charitable organizations before and after the war. However; this study date shows that most of the war disabled people are identified as untouchable caste people. Also, Tamils of Jaffna believe in reincarnation and the effects of Karma. The victims believe that their disabilities and its related exclusion are due to karmic actions in the past lives.

Low caste people with disabilities are identified as 'double victims' of the war, and they have to live their lives quietly, with little social integration. Also, the dominant caste based people with disabilities are also reflecting Hindu belief in merit making and the karma theory, where in injuries and their life of disabilities are the consequence of past misdeed and untouchable of the war. The people with disabilities and people of the society believe that their injuries are due to karmic actions in the past events of lives.

\section{Family Structure}

A family is a fundamental unit of social structure of Jaffna. The household or family was identified in association collectively rather than of the responsible individuals who formed part of it. Family members can strongly influence a condition of people with disabilities. This study found in the roles and influence of husband, wife, and children on the people with disabilities in post-war Jaffna. Under this type of family, the role of disability experience is that very surprising for a researcher. As a person has disabilities due to the war, they don't want to face him/ her in public spaces. Also, they are separated from the family members. The researcher suggested that post-war Jaffna society people with disabilities are excluded or hidden in the limited face of a house also treated differently due to other family members from to participation of the public.

The distinction between the supervision of the disabled person of the family and another family in the lens on survival and overcoming poverty, involving the energy of family members and the commitment to the home management in the post-war society. There are ex-combatants and civilians including women and men with their condition of disability; they have to live in their family. Under this family meaning of the disability is that based on gender construction of the society. There are women headed families that are identified as the separate minority group of disabilities including ex-combatants, civilian women widows because of their disabilities due to injuries. Even if they are committed to the family, they are not respected

\footnotetext{
${ }^{4}{ }^{4}$ The bottom layer of the Jaffna caste system is collectively referred to as "Panchamar", consisting of Vannār (dhoby), Ampattar (barber), Pallar (landless labourers), Nalavar (toddy tappers) and Parayar (funeral drummer) traditionally accorded untouchable status in Jaffna society. Traditionally they made up about $18 \%$ of the Jaffna population as compared to nearly $50 \%$ Vellālar population in the peninsula in the pre-war period.
} 


\section{N.Baskaran \\ People with Disabilities and Their Representation in Public Spaces: A Case Study of Post-War Jaffna}

equally, not only at par with men but with also other women of the community. Therefore, they have low self-esteem.

\section{Women Status}

The status of women in Jaffna has been highly spiritual as well as appreciable. The low status of women is based on several socio-economic and cultural factors. The war in Sri Lanka has increased the number of women with disabilities including combatant and non-combatants. Accordingly, particular kinds of customary law in Jaffna also which is deeply patriarchal and went ahead in stripping away the hitherto existing property rights enjoyed by women. The women of Jaffna developed a matrilineal succession and high status in the household as they bring in their wedding. Compared to able female and male with disabilities, based on women with disabilities in Northern Sri Lanka has been minimal social network and they don't have any property rights. Therefore, these customs have given a singular tension that affected women with disabilities. Interviews and observations show those post-war dynamics is different, as women with disabilities are overtly discriminated against.

- $\quad$ The age range of marriage $\&$ increased number of a bachelor.

- The marriage of aged people young girls with disabilities.

- A disabled woman is usually married to a disabled man.

- $\quad$ There is no grand ceremony in disabled women marriage.

- Some disabled women of high castes or middle caste might be able to do arrange the marriage with a great deal of compromise.

- Widows with disabilities are excluded from auspicious events and ceremony of their children.

- Possibilities of outside caste marriage: traditionally, in Jaffna Tamils marriages were always arranged by the parents and kinship within the same caste group. However, most of the people with disabilities have outside of caste marriage.

- Affecting the dowry system.

- Beauty: the image of the body of people with disabilities has taken a major role in the selection of life partner.

- Issues of remarriage

Disabled young women have the particular disadvantage of there being compared to their disabled men within the framed family. Poverty is an inseparable companion of most windows with disabilities. To begin with, most of them will not have any wealth or savings of their own.

\section{CONCLUSION AND RECOMMENDATIONS}

All of this study observation and data, which focus on those social attitudes of people with disabilities, are a cultural hegemony or cultural status. The day-to-day life of the people with disabilities in differences than others in lifestyles, for instance about public spaces include family, religion, and marriage gives rise to particular issues within this society and is absent from disability discourse. This paper discussed on a meaning of disabilities under three factors namely Religious discourse, family structure, and women status based on grounded theory method and coding system.

Post-war Jaffna, disability mainly addressed Tamils people of disabilities on the different residential setting (rural/urban), religious affiliation, the various status/position (caste, gender relationships dynamics) law, age, civil status (married, single, widow), levels of education and working experiences of disabilities. Disabilities are mainly due to part to the fact stigma and charity still continues to structure the way of disability is viewed in the post-war. The people with disabilities depicted there are usually crippled, and their representations are socially excluded or hidden in the limited their public spaces in the post-war Jaffna. Describing the condition of 'all' people who had injuries, but ignored ethnic minority people's experiences 


\section{N.Baskaran \\ People with Disabilities and Their Representation in Public Spaces: A Case Study of Post-War Jaffna}

which are embedded within the social-cultural background in Sri Lanka. More ever, these socio-cultural interpretations of people with disabilities are linked with another important factor such an economic and political aspect. Therefore, the researcher hopes that other researchers will continue this study and eradicate its deficiencies.

\section{ACKNOWLEDGEMENTS}

I would like to express my deepest gratitude to my undergraduate supervisor Professor Sasanka Perera (Department of Sociology, South Asian University, New Delhi, India) for providing me with his excellent guidance, care, patience during this research. Beside my supervisor, I would like to thank Dr (Mrs). Bahirathy Jeeweshwara Rasanen (Head, Department of Sociology, University of Jaffna, Sri Lanka) for her inspiring guidance to making this write up a success.

I am extremely thankful and indebted to all the research respondents from the Jaffna in Sri Lanka for sharing their experience sacrificing their time and supporting my research. Special thanks to the members and reviewers to the iCMA 2016 in the University of Sri Jayewrdenepura, Sri Lanka, and Editors of the Journal for the many valuable comments on the previous version of the paper which has improved its quality and content to the present state.

\section{REFERENCES}

- $\quad$ Addlakha Renu, Stuart Blume, Patrick Devliege, Osamu Nagase and Myriam Winance. 2009. Disability and society: A Reader: Orient Black Swan.

- Alison, Miranda 2009. Women and Political Female Combatants in Ethno National Conflict.London and New York: Routledge.

- Anderson, S and K. Whitfield. 2013. 'Social Identity \& Stroke: 'they don't make me feel like, there's something wrong with me" Scandinavian Journal of Caring Sciences, Vol. 27:820-830, CrossRef

- Baquer, Ali and Anjali Sharma. 1997.Disability: Challenges vs. Response. New Delhi: Concerned Action and Now.

- Barnes Colin and Mercer 2005. 'Disability, Work, and Welfare: Challenging the Social Exclusion of Disabled People', Work, Employment and Society, Vol. 19 (3):527-545, CrossRef

- Bunning, K and G. Steel. 2006. 'Self-concept in Young Adults with a Learning Disability from the Jewish Community' British Journal of Learning Disabilities, Vol. 35:43-49, CrossRef

- Brun, Cathrine.2008. 'Birds of freedom Young People, the LTTE, and Representations of Gender, Nationalism, and Governance in Northern Sri Lanka'. Critical Asian Studies, Vol.40 (3):399-422, CrossRef

- Campbell, Jane and Mike Oliver 1996. Disability Politics: understanding our Past, changing our Future. London and New York: Routledge.

- Chen, C and B. Shu. 2012. 'The Process of Perceiving Stigmatization: Perspectives from Taiwanese Young People with Intellectual Disability' Journal of Applied Research in Intellectual Disabilities, Vol. 25:240-251, CrossRef

- Clapton, Jayne and Jennifer, Fitzgerald. 2014. The History of Disability: A History of 'Otherness': How disable People have been marginalized through the ages and their present struggle for their human rights. Unpublished manuscript.

- Compling, Jo. 1981. Images of Ourselves: Women with Disabilities Talking. London, Boston and Henley: Routledge \& Kegan Paul.

- Dalal, A.K.2002. 'Disability rehabilitation in a traditional Indian society', Asia Pacific Disability Rehabilitation Journal, Vol.13 (2):17-26.

- Darling, R B. 2013. Disability and Identity: Negotiating Self in a Changing Society. Boulder: USA 


\section{N.Baskaran}

People with Disabilities and Their Representation in Public Spaces: A Case Study of Post-War Jaffna

- De Mel, Neloufer. 2007. Militarizing Sri Lanka: Popular Culture, Memory and Narrative in the Armed Conflict. New Delhi: Sage Publications, CrossRef

- De Silva.Nirekha. 2005.Transitional justice and women combatants in Sri Lanka. National Peace Council of Sri Lanka. Unpublished Manuscript.

- Freund, P. 2001. 'Bodies, Disability and Space: The Social Model and Disability Spatial Organisations' Disability and Society, Vol. 16 (5):689-706, CrossRef

- Giddens, Anthony. 2009. Sociology. 6th Edt. Cambridge: Polity Press.

- Goffman, Erving. 1963. Stigma: Notes on the Management of Spoiled Identity. New York: Siman and Schuster, INC.

- Hearth, Tamara. 2014. Women combatants and gender identity in contemporary conflicts- The case of the LTTE. PHD dissertation submitted to the London School of Economics and Political Science.

- Hooper, M. 1976. 'The Structure and Measurement of Social Identity' the Public Opinion Quarterly, Vol. 40 (2):154-164.

- Jan E. Stets and Peter J. Burke.2000.'Identity Theory and Social Identity Theory'. Social Psychology Quarterly, Vol. 63, (3):224-237, CrossRef

- Jodrell, David.2010.'Social-identity and self-efficacy concern for disability labels'

- Psychology Teaching Review Vol. 16. (2): 111-121.

- John Peiris R.J, Attanayake S, Daskon, L, Wickremasinghe A.R and Ameratung, S.2013,'Disability studies in Sri Lanka: priorities for action. Disability and Rehabilitation'. An International Multidimensional Journal. Vol, 36 (20):1742-1748.

- Kaufman, J and C. Johnson. 2004. 'Stigmatized Individuals and the Process of Identity' The Sociological Quarterly, Vol. 45 (4):807-833, CrossRef

- Kastoriaratechi, SK and Jayawardana PL. 2004. 'Psychological status and Physical Disabilities of Permanantly Disabled Sri Lankan Serviceman'. Hong Kong J Phychaiatry Vol 14(4): 9-14.

- Koren Ela, Bergman Yoga s, Katz Michael. 2013. Disability during service in Israel: raising awareness of gender. Vol.16 (5) $689-706$.

- Large, J. 2010. 'The Restructuring of Masculinities as a Dynamic in War and Peace' Peace Prints: South Asian Journal of Peacebuilding, Vol. 3 (1):1-11.

- Lorenz, Laura S. 2010.'Discovering a new identity after brain injury'. Sociology of Health \& Illness Vol. 32 (6):862-879, CrossRef

- Marvasti, Amir B. 2004. Qualitative Research in Sociology: An Introduction. London: Sage Publications, CrossRef

- Miles, M. (2011.). 'THE SOCIAL MODEL OF DISABILITY'. CBR and Inclusive Development, Vol 22(1): 5-15.

- Miriyagalla, Danura, 2014. 'Socio-economic reintegration of former LTTE combatants in Sri Lanka: self-employment, sustainable incomes and long-term peace' Global Change, Peace \& Security, Vol. 26(3) 251-262, CrossRef

- Ministry of Social Services. National Policy on Disability for Sri Lanka. Colombo: Ministry of Social Services; 2003.

- National Policy on Disability for Sri Lanka. 2003. Battaramulla: Ministry of Social Welfare.

- Nimmi, Gowrinathan and Kate Cronin-Furman.2015. The Forever Victims? Tamil Women in Post-War Sri Lanka: The city collage of New York. Unpublished manuscript

- Nimmi, Hutnik. 1991. Ethnic Minority identity: A Social Psychological Perspective. Oxford: Clarendon Press.

- Oliver, Micheal. 1996. Understanding Disability: From Theory to Practice. New York St: Martin press, CrossRef

- Orijuela, Camilla. 2008. The Identity politics of Peace building Civil Society in warTorn Sri Lanka London-New Delhi- Sinhapore: SAGE Los Angeles.

- Perera, S. 2011(a). 'The Construction of Masculinity and Bravery in War: The Case of Sri Lanka' Asian Leadership Fellow Programm 2010 Program Report: Rethinking 
Global Challenges Asian Intellectuals in Dialogue. Tokyo: International House of Japan \& Japan Foundation

- Perera, Amantha. April, 2015.'Maimed by Conflict, Forgotten by Peace: Life through the Eyes of the War-Disabled.'http://www.ipsnews.net/2015/02/maimed-byconflict-forgotten-by-peace-life-through-the-eyes-of-the-war-disabled. (Last accessed on 10 April 2016).

- Reeve, Donna. 2002.Negotiationg Psycho-emotional Dimension of Disability and their Influence on Identity Constructions' Disability and Society, 17 (5):493-508, CrossRef

- Samararatne, Dinesha and Soldatic, Karen . 2014. Rural disabled women's social inclusion in post-armed conflict Sri Lanka. Submitted to the UNSW Australia and Social Scientists' Association, Sri Lanka.

- Santrock, 2007, Essentials of life-span development, Mcgraw- Hill Higher Education

- Scruton, Roger. 1987.'Notes on the sociology of war'. The British Journal of Sociology, Vol. 38, (3):295-309, CrossRef

- Shakespeare, Tom 1993. 'Disabled People's Self-Organization: A New Social Movement?' Disability, Handicap and Society, Vol. 8 (3):249-264, CrossRef

- Somasundaram, Daya.2010. 'Collective trauma in the Vanni - a qualitative inquiry into the mental health of the internally displaced due to the civil war in Sri Lanka' International Journal of Mental Health Systems, Vol. 4: (22):2-31, CrossRef

- Summerfield, Derek.1996. The Impact of War and Atrocity on Civilian Populations: Basic Principles for NGO Interventions and a Critique of Psychosocial Trauma Projects. Medical Foundation series London.

- Tambiah Yasmin.2005, 'Turncoat Bodies- Sexuality and Sex Work under Militarization in Sri Lanka'. GENDER \& SOCIETY, Vol. 19 (2):243-261, CrossRef

- Taylor, S. J. 2000. '"You're Not a Retard, You're Just Wise": Disability, Social Identity, and Family Networks' Journal of Contemporary Ethnography, Vol. 29 (1):58-92, CrossRef

- Wang, Peng. 2011.'Women in the LTTE: Birds of Freedom or Cogs in the Wheel?', Journal of Politics and Law, Vol. 4 (1) :100- 108, CrossRef

- Wastson Nick, Alan and Carol. 2012. Routledge Handbook of Disabulity Studies.New York: Routledge. 